\title{
PENILAIAN SENSORIS DAGING DAN BAKSO DARI EMPAT GALUR AYAM BURAS YANG DIBERI JAMU FERMENTASI
}

\author{
Isye J. Liur*, Astri D. Tagueha \\ Jurusan Peternakan, Fakultas Pertanian, Universitas Pattimura \\ Jln. Ir. M. Putuhena Kampus Poka, Ambon 97233 \\ *Email : isye.jean@gmail.com
}

\begin{abstract}
ABSTRAK
Penelitian ini bertujuan untuk mengetahui kualitas sensoris daging dan bakso dari empat galur ayam buras yang diberi jamu fermentasi. Penelitian ini menggunakan 4 perlakuan (G1 : ayam kampung, G2 : ayam bangkok, G3 : ayam KUB, dan G4 : ayam silangan bangkok), 3 replikasi dan setiap replikasi dinilai oleh 20 panelis. Jamu fermentasi diberikan dalam dosis dan frekuensi yang sama selama 3 bulan pemeliharaan, demikian pula pakan komersil yang sama. Hasil analisis Kruskal Wallis menunjukkan : (1) terdapat perbedaan warna dan daya terima namun tidak pada aroma dan tekstur daging, dan (2) terdapat perbedaan warna namun tidak pada aroma, tekstur, dan daya terima untuk bakso dari empat galur ayam buras yang diberi jamu fermentasi.
\end{abstract}

Kata kunci: Kualitas sensoris, ayam buras, jamu fermentasi

\section{SENSORY QUALITY OF MEAT (CARCASS) AND MEAT BALL FROM FOUR STRAIN OF NATIVE CHICKEN WHOSE RECEIVE FERMENTED HERB}

\begin{abstract}
The objective of this research was to known sensory quality of meat (carcass) and bakso from four strain of native chicken whose receive fermented herbs. This study used four treatments (G1 - Native, G2 - Bangkok, G3 - KUB, G4 - Bangkok Hybrid) and three replications, each of them was observed by 20 panelists. During three months of observation, each treatment received same dosage and frequency of fermented herbs and also the number of commercial feed. The results showed that : (1) the sensory quality of meat (carcass) revealed the differences in colour and acceptability but not in flavor and texture, and (2) the sensory quality of bakso revealed the differences only in colour, yet its absent in flavor, texture, and tenderness.
\end{abstract}

Key words: Sensory quality, native chicken, fermented herbs

\section{PENDAHULUAN}

Daging ayam buras mempunyai kandungan gizi cukup lengkap, pada 100 gram daging segar terkandung $18,1 \%$ protein, $12 \%$ lemak, dan $60-70 \%$ air. Kandungan vitamin B akan keluar pada saat daging direbus, sementara mineral terdiri dari kalsium, magnesium, natrium, seng, kuprum, dan mangan (Dewi, 2013). Selain itu, cita rasa yang khas dari daging ayam buras serta tingginya kesadaran untuk mengonsumsi produk organik juga menjadi faktor stabilnya permintaan komoditi ini walaupun harganya tinggi di pasaran. Ditjeknnak (2018) menunjukkan pada tahun 2016, konsumsinya per kapita mencapai $5,68 \mathrm{~kg}$ per tahun atau lebih tinggi $11,22 \%$ dibanding tahun sebelumnya. Survei Ekonomi Nasional (Susenas) melaporkan, daging ayam kampung berkontribusi $12,33 \%$ terhadap konsumsi daging ayam masyarakat Indonesia (Kementerian Pertanian, 2015).
Ayam buras di Indonesia memiliki keragaman fenotip dan genotip, terdapat 32 rumpun asli yang berhasil diidentifikasi (Nataamijaya, 2000). Beberapa galur seperti ayam Kampung, ayam Bangkok, ayam KUB, dan ayam Silangan Bangkok merupakan rumpun asli atau silangannya. Ayam Kampung adalah hasil domestikasi ayam hutan merah dan ayam hutan hijau (Sarwono, 2005), sementara ayam KUB merupakan ayam Kampung murni hasil seleksi galur betina selama 6 generasi untuk tujuan produksi telur. Ayam Bangkok dipelihara sebagai tipe petarung sedangkan Silangan Bangkok bertujuan untuk pewarisan sifat unggul dari ayam Bangkok dan tipe petelur (Mokodongan dkk., 2017).

Upaya perbaikan kualitas daging ayam telah dilakukan oleh banyak peneliti, misalnya jus nenas untuk tekstur (Rugayah, 2009), lempunyang untuk warna (Jarmani dan Nataamijaya, 2001), kombinasi bawang putih dan temulawak (Dono, 2010) atau jahe 
(Pratama dkk., 2012) untuk perbaikan kadar kolesterol dan keempukan daging.

Kombinasi beberapa herbal yang diracik untuk suplementasi pakan terbukti efektif meningkatkan imunitas, memperbaiki produktivitas, maupun menurunkan FCR (Zainuddin dan Wakradihardjo, 2002; Sumardi, 2006; Puslitbang, 2015; Muthusamy et al., 2017). Fermentasi ramuan jamu dengan EM-4 juga terbukti mempengaruhi kadar kolestrol dan profil serum darah ayam (Apriansyah, 2010).

Penilaian sensoris turut menentukan penerimaan konsumen terhadap pangan, termasuk daging dan olahannya. Penilaian terhadap warna, rasa atau aroma, keempukan dan daya terima dianggap cukup mewakili preferensi konsumen (Soeparno, 2009; Setyaningsih dkk., 2010).

Tekstur daging ayam buras yang alot tentunya berdampak pada produk olahan yang dihasilkan, apalagi dari empat galur yang berbeda. Oleh karena itu pemberian jamu fermentasi diharapkan tidak hanya memperbaiki imunitas dan produksi, tetapi juga kualitas daging. Penelitian ini bertujuan untuk mengetahui kualitas sensoris dari daging dan bakso yang berasal dari empat galur ayam buras.

\section{BAHAN DAN METODE}

Penelitian ini terlaksana mulai Juli - Oktober 2017 berlokasi di Unit Perkandangan, Jurusan Peternakan Universitas Pattimura menggunakan 64 DOC dari 4 galur berbeda (ayam Kampung, ayam Bangkok, ayam KUB, dan ayam Silangan Bangkok) dengan pakan khusus ayam buras yaitu AD1 dan AD2. Kandang percobaan didesain berbentuk battery dan disekat sebanyak total replikasi. Uraian sistem pemeliharaan secara lengkap dapat dilihat pada Tagueha dkk. (2018).

Pakan per individu diberikan berdasarkan umur dengan rincian sebagai berikut: 7 gram/hari (umur 1-7 hari), 19 gram/hari (umur 8-14 hari), 34 gram/hari (umur 15-21 hari), 47 gram/hari (umur 22-28 hari), 58 gram/hari (umur 29-35 hari), dan 66 gram/hari (umur 36-42 hari).

Komposisi jamu fermentasi mengacu pada formula Zainuddin dan Wakariharja (2002). Bahanbahan yang dibutuhkan untuk 10 liter jamu yaitu 250 gram bawang putih, 250 gram kencur, 125 gram jahe, 125 gram lengkuas, 125 gram kunyit, 125 gram temulawak, 62.5 gram kayu manis, 62.5 gram daun sirih, 62.5 gram daun mahkota dewa, $250 \mathrm{ml}$ gula merah, dan $250 \mathrm{ml}$ EM-4. Prosedur pembuatannya dapat dilihat pada Gambar 1.

Pemeliharaan dilakukan selama 2 bulan dengan dosis jamu sama untuk semua perlakuan, yaitu $10 \mathrm{ml}$ jamu/liter air. Pemberian air minum dilakukan secara ad libitum.

Pada akhir pemeliharaan, 12 ekor ayam dipilih secara acak untuk pemeriksaan sensoris daging dan bakso sebagai produk olahannya.

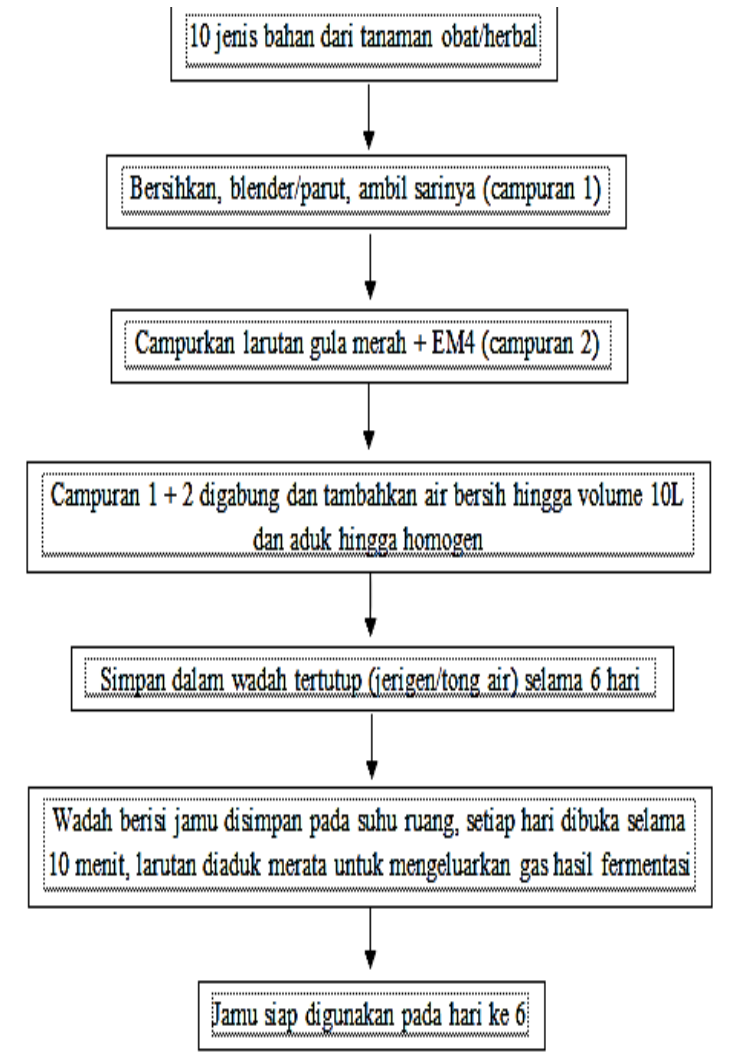

Gambar 1. Prosedur pembuatan jamu dari kombinasi tanaman obatherbal

Komposisi adonan untuk pembuatan bakso, terdiri dari : $1 \mathrm{~kg}$ daging ayam, 250 gr tepung tapioca, 25 gr garam, 40 gr bawang putih, 9 gr merica, dan 300 gram es batu. Adonan kemudian dibuat bulatan dengan diameter 1,5 - $2 \mathrm{~cm}$ dan direbus dengan air mendidih hingga terapung.

Indikator sensoris untuk penilaian daging mentah yang belum diolah diuraikan pada Tabel 1, sedangkan untuk penilaian bakso terlihat pada Tabel 2.Penilaian tersebut dilakukan oleh 20 orang panelis.

Data yang diperoleh dianalisis dengan pendekatan non parametrik yaitu uji Hedonic Kruskal Wallis.

Tabel 1. Indikator penilaian kualitas sensoris daging

\begin{tabular}{|c|c|c|c|c|}
\hline Skor & Warna & Aroma & Tekstur & $\begin{array}{l}\text { Daya } \\
\text { terima }\end{array}$ \\
\hline 5 & Putih & $\begin{array}{l}\text { Sangat } \\
\text { suka }\end{array}$ & $\begin{array}{c}\text { Sangat } \\
\text { halus }\end{array}$ & $\begin{array}{l}\text { Sangat } \\
\text { suka }\end{array}$ \\
\hline 4 & $\begin{array}{c}\text { Putih } \\
\text { kekuningan }\end{array}$ & Suka & Halus & Suka \\
\hline 3 & $\begin{array}{c}\text { Agak } \\
\text { kuning }\end{array}$ & $\begin{array}{l}\text { Agak } \\
\text { suka }\end{array}$ & $\begin{array}{l}\text { Agak } \\
\text { halus }\end{array}$ & $\begin{array}{l}\text { Agak } \\
\text { suka }\end{array}$ \\
\hline 2 & Kuning & $\begin{array}{l}\text { Tidak } \\
\text { suka }\end{array}$ & Kasar & $\begin{array}{l}\text { Tidak } \\
\text { suka }\end{array}$ \\
\hline 1 & $\begin{array}{l}\text { Sangat } \\
\text { kuning }\end{array}$ & $\begin{array}{c}\text { Sangat } \\
\text { tidak } \\
\text { suka } \\
\end{array}$ & $\begin{array}{c}\text { Sangat } \\
\text { kasar }\end{array}$ & $\begin{array}{c}\text { Sangat } \\
\text { tidak suka }\end{array}$ \\
\hline
\end{tabular}


Tabel 2. Indikator penilaian kualitas sensoris bakso

\begin{tabular}{|c|c|c|c|c|}
\hline Skor & Warna & Aroma & $\begin{array}{c}\text { Keempuk- } \\
\text { an }\end{array}$ & $\begin{array}{c}\text { Daya } \\
\text { terima }\end{array}$ \\
\hline 5 & Putih & $\begin{array}{c}\text { Sangat } \\
\text { suka }\end{array}$ & $\begin{array}{l}\text { Sangat } \\
\text { empuk }\end{array}$ & $\begin{array}{c}\text { Sangat } \\
\text { suka }\end{array}$ \\
\hline 4 & $\begin{array}{c}\text { Putih abu- } \\
\text { abu }\end{array}$ & Suka & Empuk & Suka \\
\hline 3 & $\begin{array}{c}\text { Agak } \\
\text { abu-abu }\end{array}$ & $\begin{array}{l}\text { Agak } \\
\text { suka }\end{array}$ & $\begin{array}{l}\text { Agak } \\
\text { empuk }\end{array}$ & $\begin{array}{c}\text { Agak } \\
\text { suka }\end{array}$ \\
\hline 2 & Abu-abu & $\begin{array}{l}\text { Tidak } \\
\text { suka }\end{array}$ & Alot & $\begin{array}{l}\text { Tidak } \\
\text { suka }\end{array}$ \\
\hline 1 & $\begin{array}{l}\text { Abu-abu } \\
\text { kehitaman }\end{array}$ & $\begin{array}{c}\text { Sangat } \\
\text { tidak } \\
\text { suka }\end{array}$ & $\begin{array}{c}\text { Sangat } \\
\text { alot }\end{array}$ & $\begin{array}{c}\text { Sangat } \\
\text { tidak } \\
\text { suka }\end{array}$ \\
\hline
\end{tabular}

\section{HASIL DAN PEMBAHASAN}

\section{Kualitas Sensoris Daging}

Hasil penelitian menunjukkan daging segar yang berasal dari 4 galur ayam buras memiliki perbedaan yang nyata/signifikan untuk warna dan daya terima (Tabel 3). Panelis menilai warna daging segar berkisar dari putih kekuningan hingga agak putih dan menyatakan kesukaannya terhadap tampilan tersebut. Perbedaan warna karkas ini diperkirakan berkaitan dengan perbedaan galur ayam yang dipakai. Hasil ini sejalan dengan pendapat Soeparno (2009) yang menyatakan warna daging sangat dipengaruhi oleh pakan, spesies, bangsa, umur, jenis kelamin, tingkat aktivitas dan tipe otot, $\mathrm{pH}$, serta kandungan oksigen.

Tabel 3. Rata-rata skor penilaian terhadap kualitas sensoris daging ayam dari 4 galur

\begin{tabular}{ccccc}
\hline Galur & Warna* & Aroma & Tekstur & $\begin{array}{c}\text { Daya } \\
\text { Terima* }\end{array}$ \\
\hline 1 & 4,55 & 4,10 & 4,10 & 4,20 \\
2 & 4,55 & 4,15 & 3,85 & 4,05 \\
3 & 4,30 & 3,85 & 3,50 & 3,85 \\
4 & 4,15 & 3,80 & 3,55 & 3,85 \\
\hline
\end{tabular}

*Terdapat perbedaan yang nyata $(\mathrm{p}<0,05)$

Perbedaan tersebut tidak ditemukan pada aroma dan tekstur. Seluruh sampel daging menunjukkan persamaan aroma (khas karkas unggas) dan teksturnya. Beberapa faktor yang mempengaruhi aroma karkas yaitu umur ternak, jenis pakan, serta lama dan kondisi penyimpanan setelah dipotong. Tekstur daging berkaitan erat dengan keempukan atau kealotan daging ketika dimasak dan dipengaruhi oleh tiga komponen utama yaitu jaringan ikat, serabut otot dan jaringan adipose (Soeparno, 2009). Kesamaan respon panelis terhadap aroma dan tekstur dapatlah dipahami mengingat kecilnya variasi umur ayam yang dipelihara, pemeliharaan secara ekstensif dengan pakan dan jamu yang seragam dan terkontrol, masa pemeliharaan singkat, panelis langsung melakukan penilaian setelah pemotongan sehingga tidak ada tindakan penyimpanan yang dapat mengubah aroma daging, serta keseragaman otot dada yang dipakai sebagai sampel.

Peneliti lain yang menggunakan ekstrak herbal seperti Sumac dan Rosemary menemukan pencelupan karkas pada kedua perlakuan tidak mengubah warna dan aroma karkas unggas, tetapi dapat berfungsi ganda sebagai agen dekontaminan dan preservative karena mengurangi TPC, Coliform, E-coli, serta Staphylococus sekaligus memperpanjang masa simpan daging (Khalafalla et al., 2016). Lebih lanjut, kualitas sensoris daging seperti aroma dan tekstur tidak akan berubah walaupun pergantian pakan dan lingkungan pemeliharaan diperkenalkan sebelum ayam berumur 6 bulan (de Almeida dan Zuber, 2010). Sementara itu, peneliti lain mengungkapkan perbedaan tekstur dan flavor dapat dimanipulasi melalui manajemen pemeliharaan (Fanatico et al., 2007).

Daya terima sebagai aspek sensoris yang terakhir dinilai menunjukkan adanya perbedaan di antara 4 galur ayam yang diteliti. Adanya variasi warna daging namun kesamaan pada aroma dan tekstur turut mempengaruhi penilaian panelis. Daya terima tertinggi dan terendah berturut-turut adalah daging yang berasal dari galur ayam Kampung serta ayam KUB dan Silangan Bangkok. Seluruh sampel dinilai memiliki tekstur halus, tampilannya segar mengkilat, dan aromanya segar (tidak anyir) khas daging sehingga dapat diterima/disukai. Soeparno (2009) dan Setyaningsih dkk. (2010) menyatakan daya terima atau kepuasaan merupakan penilaian subjektif serta dipengaruhi oleh respon fisiologis dan sensoris

\section{Kualitas Sensoris Bakso}

Preferensi konsumen terhadap suatu produk dipengaruhi oleh berbagai faktor, diantaranya adalah warna.Selain kandungan myoglobin daging dan tambahan bumbu, utamanya warna bakso dipengaruhi oleh pati yang dipakai sebagai filler.Warna putih biasanya dihasilkan oleh filler tepung tapioka (Moorthy, 2004).

Tabel 4. Rata-rata skor penilaian terhadap kualitas sensoris bakso dari 4 galur ayam

\begin{tabular}{ccccc}
\hline Galur & Warna* & Aroma & $\begin{array}{c}\text { Keempuk } \\
\text {-an }\end{array}$ & $\begin{array}{c}\text { Daya } \\
\text { Terima }\end{array}$ \\
\hline 1 & 4,0 & 4,0 & 3,95 & 4,05 \\
2 & 3,95 & 3,9 & 3,95 & 4,10 \\
3 & 4,15 & 4,0 & 3,90 & 4,05 \\
4 & 3,80 & 3,95 & 3,85 & 4,10 \\
\hline
\end{tabular}

*Terdapat perbedaan yang nyata $(\mathrm{p}<0,05)$

Hasil penelitian menunjukkan terdapat perbedaan warna bakso yang berasal dari 4 galur ayam Kampung yaitu berkisar dari agak abu-abu hingga putih abu-abu. Bakso dari daging ayam KUB memiliki warna tertinggi, sedangkan yang terendah dari daging ayam Silangan Bangkok (Tabel 4). Perbedaan ini 
ternyata ditemukan sebelum daging diolah menjadi bakso (Tabel 3). Oleh karena keempat galur mendapatkan dosis dan frekuensi pemberian jamu fermentasi yang sama demikian pula komposisi adonan dan bagian yang otot daging yang diolah. Diduga adanya perbedaan warna disebabkan oleh perbedaan kandungan myglobin namun hal tersebut haruslah diuji lebih lanjut. Apabila kandungan myglobin berhubungan dengan hemoglobin maka temuan kandungan hemoglobin pada galur ayam Bangkok, ayam Kampung, dan ayam peranakan yaitu secara berturut-turut $11,85 \mathrm{mg} / \mathrm{dl}, 11,65 \mathrm{mg} / \mathrm{dl}$, dan 12,17 $\mathrm{mg} / \mathrm{dl}$ oleh Alfian dkk. (2017) dapat dipakai sebagai dasar untuk menguji hipotesis tersebut.

Tidak ada perbedaan aroma, keempukan, dan daya terima pada bakso dari keempat galur ayam buras. Bakso yang dihasilkan memiliki aroma khas bakso, teksturnya empuk, dan disukai oleh panelis. Tekstur bakso yang empuk disebabkan karena protein daging berfungsi sebagai perekat sehingga strukturnya lebih kompak serta berperan juga sebagai emulsifier (Hasniar dkk, 2019). Hal lain yang diperkirakan tidak memberikan pengaruh terhadap kualitas sensoris bakso adalah umur ketika dipotong, yaitu \pm 4 bulan dan tergolong dalam ayam muda yang tekstur dagingnya tidak terlalu alot.

Jika dirinci per aspek sensoris, panelis memberikan nilai tertinggi untuk kesukaannya pada aroma bakso daging ayam Bangkok, tekstur yang empuk berasal dari ayam Kampung dan ayam Bangkok, sedangkan daya terima tertinggi adalah bakso daging ayam Bangkok dan Silangan Bangkok. Perlu ditambahkan, tingkat kesukaan terhadap aroma bakso juga disebabkan oleh bumbu-bumbu selama prossesing hingga pemasakan. Lebih lanjut, aroma turut dipengaruhi oleh volatile yang diproduksi ketika lemak dipanaskan (Fanatico et al., 2007) dan terdapat 450 komponen untuk menguji flavor daging unggas (Parker et al., 2006).

Penilaian keempukan menurut Soeparno (2009) secara keseluruhan meliputi kemudahan awal penetrasi daging ke dalam gigi, kemudahan pengunyahan menjadi potongan lebih kecil, dan residu yang tertinggal setelah pengunyahan. Sementara itu, penerimaan dan kesukaan konsumen dapat diuji secara afeksi (Setyaningsih dkk., 2010) dan berdasarkan hasil penelitian bakso dari keempat galur dapat diterima dengan baik.

\section{SIMPULAN}

Empat galur ayam buras yang diberi jamu fermentasi menunjukkan perbedaan kualitas sensoris daging terutama pada warna daging dan daya terima. Setelah diolah menjadi bakso, perbedaan tersebut hanya ditemukan pada warna bakso yang dihasilkan.

\section{DAFTAR PUSTAKA}

Alfian, Dasrul, dan Azhar. 2017. Jumlah Eritrosit, Kadar Hemoglobin, dan Nilai Hematokrit Ayam Bangkok, Ayam Kampung, dan Ayam Peranakan. Jimvet. 1(3): 533-539.

Apriansyah, B. D. 2010. Pengaruh Pemberian Jamu Ternak Terhadap Kadar Kolesterol dan Profil Serum Darah Ayam Arab (Gallus turcicus). [Skripsi]. Bogor: Fakultas Peternakan, Institut Pertanian Bogor.

De Almeida, M. A., and U. Zuber. 2010. The Effect of The Naked Neck Genotype (Nana), Feeding and Outdoor Rearing on Growth and Carcass Characteristics of Free Range Broilers in a Hot Climate. Tropical Animal Health Production. 42(1): 99-107.

Dewi, S.H.C. 2013. Kualitas kimia daging ayam kampung dengan ransum berbasis Konsentrat broiler. Jurnal AgriSains. 4(6): 42-49.

Ditjennak. 2018. Statistik Peternakan dan Kesehatan Hewan. http://ditjenpkh.pertanian.go.id/. [04/09/2019].

Dono, N.D. 2010. Kualitas Daging Ayam Boiler yang Mendapatkan Tepung Bawang Putih dan Tepung Temulawak dalam Ransum. Jurnal Ilmu Ternak dan Veteriner. 15(2): 81-87.

Fanatico, A.C., P.B. Pillai., J.L. Emmert., E.E. Gabur., J.F. Meullenet., and C.M. Owens. 2007. Sensory Attributes of Slow-and Fast Growing Chicken Genotypes Raised Indoors or With Outdoor Access. Poultry Science. 86: 2441-2490.

Hasniar, M. Rais, dan R. Fadilah. 2019. Analisis Kandungan Gizi dan Uji Organoleptik Pada Bakso Tempe Dengan Penambahan Daun Kelor (Moringa oleifera). Jurnal Pendidikan Teknologi Pertanian. 5: 189200.

Jarmani, S.N., dan A.G. Nataamijaya. 2001. Penampilan ayam ras pedaging dengan menambahkan tepung lempuyang (Zingiber aromaticum Val.) di dalam ransum dan kemungkinan pengembangannya. Seminar Nasional Teknologi Peternakan dan Veteriner. Puslitbang Peternakan. Bogor.

Kementerian Pertanian. 2015. Outlook Komoditas Pertanian Sub Sektor Peternakan Daging Ayam. Pusat Data dan Sistem Informasi Pertanian. Jakarta: Sekjen Kementan.

Khalafalla, F.A., F.H.M. Ali., J.M. Ouf., and A.M.M.A. Mosa. 2016. Decontamination of Broiler Carcasses Skin Using Medicinal 
Herbal Extracts. Journal of Veterinary Medical Research. 23(1): 26-34.

Mokodongan, A.R., F. Nangoy., J.R. Leke., dan Z. Poli. 2017. Penampilan Pertumbuhan Ayam Bangkok Starter yang Diberi Pakan Dengan Level Protein Berbeda. Jurnal Zootek. 37(2): 426-435.

Moorthy, S.N. 2004. Tropical Sources of Starch. Baco Raton, Florida: CRC Press.

Muthusamy, S.P., T.R.G.K Murthy, and V. Thiagarajan. 2017. Effect of Blend Supplement on Haematology and Serum Biochemistry in Commercial Layer Chicken. Journal of World Poultry Research. 7(2): 48-56.

Nataamijaya, A.G. 2000. The Native Chickens of Indonesia. Buletin Plasma Nutfah. (11)1: 16.

Parker, K., A. Arkoudi., D.S. Mottram., and A.T. Dodson. 2006. Aroma Formation in Beef Muscle and Beef Liver. Journal Animal Science. 33: 333-350.

Pratama, A.Y., U. Atmomarsono, dan L.D. Mahfudz. 2012. Pengaruh Penggunaan Tepung Jahe (Zingiber offinale) dalam Ransum Terhadap Perlemakan dan Trigliserida Ayam Kampung. Animal Agriculture Journal.1(1): 733 - 741 .

Puslitbang. 2015. Jamu Ternak Fermentasi Peningkat Imunitas. http://perkebunan.litbang.pertanian.go.id. [04/09/2019].
Rugayah, N. 2009. Kualitas Organoleptik Daging Ayam Kampung dengan Pemberian Jus Nenas Muda dan Lama Perendaman Berbeda. Prosiding Seminar Nasional Teknologi Peternakan dan Veteriner. Hal $667-673$.

Sarwono, B. 2005. Beternak Ayam Buras. Jakarta: Penebar Swadaya.

Setyaningsih D., A. Apriyanto, dan M.P. Sari. 2010. Analisis Sensori. Bogor: IPB Press.

Soeparno. 2009. Ilmu dan Teknologi Daging. Yogyakarta: UGM Press.

Sumardi. 2006. Sumardi dan Jamu Tahan Flu Burung. Dilaporkan C.Wahyu Haryo dalam Harian Kompas tanggal 17 Juli 2006. hlm 16.

Tagueha, A.D., I.J. Liur, dan Rajab. 2018. Performa Produksi Beberapa Galur Ayam Buras yang Diberi Jamu Fermentasi. Agrinimal Jurnal Ilmu Ternak dan Tanaman. 6(1): 39-44.

Zainuddin, D., dan E. Wakradihardjo. 2002. Racikan Ramuan Tanaman Obat dalam Bentuk Larutan Jamu dapat Mempertahankan dan Meningkatkan Kesehatan serta Produktivitas Ternak Ayam Buras. Prosiding Seminar Nasional XIX Tumbuhan Obat Indonesia.Kerjasama POKJANAS Tumbuhan Obat Indonesia dengan Puslit Perkebunan. Bogor. 